Годищњак Филозофског̄ факулиеиейа у Новом Саду, Къиг̄a ХХХVIII (2013)

Annual Review of the Faculty of Philosophy, Novi Sad, Volume XXXVIII (2013)

Владан С. Гавриловић, Ненад Ђ. Нинковић Филозофски факултет Универзитета у Новом Саду

УДК 341.78(497+439.5+470)

Петровић В.“"1742/1766“"

341.78 Петровић В.“"1742/1766“"

Оригинални научни рад

\title{
ДИПЛОМАТСКЕ МИСИЈЕ АРХИМАНДРИТА И МИТРОПОЛИТА ВАСИЛИЈА ПЕТРОВИЋА У МЛЕТАЧКОЈ РЕПУБЛИЦИ И ХАБЗБУРШКОЈ МОНАРХИЈИ*
}

Цетињски митрополит Василије Петровић играо је важну улогу у прошлости Црне Горе, Брда и Херцеговине од 1742. када је привремено управљао Митрополијом у име име стрица митрополита Саве, до 1766. када је умро у Русији. Способни и амбициозни јерарх знао је колике су реалне снаге Црне Горе и да је за било коју акцију, а пре свега ону која би водила еманципацији од османске власти, њој неопходна подршка и помоћ утицајне и моћне стране силе. у том циљу своју политику је покушавао да веже, зависно од догађаја и времена, за Млетачку републику, Хабзбуршку монархију и Руско царство. Највише успеха имао је у последњој држави, али је искуство у преговорима и настојањима да моћне владаре заинтересује за Црну Гору стекао у прве две. Боравак у Хабзбуршкој монархији био је у том смислу вема значајан, нарочито први, који је трајао са прекидима од 1749. до 1751.

Кључне речи: Василије Петровић, Црна Гора, Млетачка република, Хабзбуршка монархија, Руско царство, Карловачка митрополија, Павле Ненадовић.

Историја племена Црне Горе, Брда и Херцеговине испуњена је од последње две деценије XVII и током већег дела XVIII века настојањем да се ослободе османске власти. На остваривању овог плану радили су цетињски митрополити, како они који су се налазили на челу митрополије пре доласка првог Петровића Његоша-митрополита Данила, тако и они који су га наследили. Заслугом јерархије конкретизована је, у време Великог бечког рата (1683-1699), политика еманципације од османске власти, а њен најзначајнији заговорник био је митрополит Висарион Бориловић. Под његовом управом, по вољи народа, дошло је de facto до збацивања једне (османске) и преласка под другу туђинску власт (млетачку). Иако ова чињеница није имало значаја за велике силе које су се на простору Црне Горе, Херцеговине и Брда приликом склапања мира у Сремским Карловцима (26. јануар 1699) определиле за status quo ante bellum, од огромног је значаја за српски народ на њему. Искуство у овом рату, више него и у једном пре њега, показало је

* gavra1@yahoo.com 
јерархији, главарима и народу да је борба против Османлија могућа, али пре свега уз ослањање на савезника, у овом случају на најближег-Млетачку републику. Са оваквим наслеђем преузео је управу Митрополијом 1697. Данило Петровић, син угледног трговца и млетачког пријатеља Шћепана Калуђерова из Његуша, чиме је почела ера митрополита из ове куће (Томић 1907 : passim; Томић б.г. 91-122; Мијушковић 1954 1-27; Петровић 1981: 64-85; Дашић 2011: 82-97; Микавица-Васин-Нинковић 2013: 49-60).

Новоизабрани митрополит Данило, чија је младост прошла управо у време поменутог рата, најбоље је познавао све његове последице, као и карактер османске власти. С тога не чуди што је упрвао он борбу за ослобођење подигао на нови ниво, у којем се српски народ није ослањао само на савезнике, него често и на искључиво сопствене снаге. Овакав је био нови рат (1711/1712) без обзира што је у њега владика ушао на позив Русије, јер му она није могла да помогне. Све је то довело до турске интервенције у два похода, 1712. Ахмед-паше Шапчалије и 1714. Нуман-паше Кеприлија током којих је Црна Гора претрпела велике материјалне и људске губитке, али који њено становништво нису одвратили од даље борбе, напротив увели су је поново у рат на страни Млетачке републике. Неповерљив према Венецији, увиђајући да није могуће ослобођење задобити сопственим снагама владика Данило почиње спољнополитичку преоријентацију и окреће се најпре далекој Русији, а потом, привремено, Хабзбуршкој монархији. На ово га је упућивало и искуство већег дела српског народа, који је своју судбину током ратова против Османског царства везивало за Хабзбурговце и њихове политичке тежње. Иако је од 1718. до смрти 1735. радио највише на сређивању унутрашњих прилика и није потстицао устанке против Османлија, ратно искуство из периода 1683-1718, дипломатско наслеђе, њега и његових претходника и османска пустошења оставили су јасно усмерен пут којим би требало ићи (Томић 1920: 161-191; Томић 1932: 47-114; Станојевић 1955: passim; Мијушковић 1955: 173-211; Распоповић 1996: 39-41; Петровић 1997: 7-84; Дашић 2011: 260-270; Микавица-Васин-Нинковић 2013: 61-84).

Рођак и Данилов наследник на митрополијском трону владика Сава Петровић брзо се показао као особа која није дорасла започетом процесу ослобођења. Свега две године после његовог доласка на чело митрополије дошло је до рата Хабзбуршке монархије и Османског царства који је подржао патриjapx Арсеније IV Јовановић Шакабента, али и народ, стављајући се одмах на хришћанску страну. Патријарх и главари брдских племена, пре свих кучки војвода Радоња Петровић настојали су да за акцију и рат против Османлија заинтересују и владику Саву, али су сви њихови покушаји остали без успеха. На наговор Венеције митрополит, гувернадур и црногорски главари остали су неутрални, што никако није било у складу са дотадашњом ратничком традицијом. Управо на ово је указивао патријарх, али резултата није било, јер је владика слушао само оно што му је Венеција преко которских провидура поручивала. Већ овде се јасно показало да ће митрополит Сава бити личност која избегава конфликте и настоји да испуни пре свега све оно 
што од њега захтева Венеција, чак и на штету сопственог народа. У таквим околностима било је питање времена када ће се у Црној Гори појавити једна личност, јачег карактера, амбициозна, са каквом-таквом визијом и преузети примат од владике Саве. Страхујући и сам од ове могућности, а у нади да ће ојачати свој положај, митрополит се упутио у Русију 1742. одакле се у Црну Гору вратио у другој половини 1744. Међутим, његов пут није имао никаквих политичких последица, нити је он такве амбиције показао, али је био основа управо онога од чега је највише страховао, током његовог одсутва појавила се личност у чију је сенку све више падао. Био је то, архимандрит цетињског манастира Василије Петровић, који је свој успон управо дуговао рођаку митрополиту Сави, јер га је он поставио на чело Цетињске митрополије током боравка у Русији (Станојевић 1962: 380-385; ИЦГ 1975: 289-290; Петровић 1981: 149-165; Микавица-Васин-Нинковић 2013: 85-89).

По одласку митрополита Саве архимандрит Василије је наставио његову политику према Венецији и радио на одржавању пријатељских односа са њом. Међутим, није успевао да спречи упаде Црногораца на млетачку територију и сукобе становништва, због чега су Млечани увели порез од 4 солда на сваког Црногорца који би дошао у Котор. Поред овога, протерали су неке црногорске главаре што се сматрало великом увредом, која је резултирала тиме да су Млечани током октобра 1743. год. похапсили поједине главаре. Све ово је изазвало револт Црногораца, а Василије је протествовао код далматинског провидура Ђиролама Кверинија тражећи да се са положаја надинтенданта у Котору уклони Никола Болица (Грбичић), и которски провидур Ђироламо Албрици. Црногорци су сматрали да је Болица главни инспиратор хапшења главара, а да Албрици прихвата све његове предлоге усмерене против њих. Сукоб је привремено решен на састанку у Котору, када су Црногорци дали таоце, али су пазари за њих били затворени, што је узроковало несташицу жита. Архимандрит Василије је зато поново протествовао код Кверинија (јануар 1744), али без успеха пошто су таоци побегли из Котора. Сердар Станислав (Стано) Радоњић увераво је провидура да ће проблем са црногорске стране бити решен и после бекства таоца, док је Василије обећавао да ће их послати назад. У таквим околностима Василије је решио да лично оде у Венецију и ту са Сенатом реши најважнија питања која су се тицала њихових односа (Томић 1920 Црногоорски митиройолити: 214-215; Томић 1931: 33-35, 37-39; Распоповић 1996: 40-45; Микавица-Васин-Нинковић 2013: 87-90).

Архимандрит је стигао у Венецију средином априла 1744. године са шест пратилаца и задржао се тамо четири месеца. У писмима која је писао и на којима је фалсификовао потписе црногорских главара Василије је себе представљао као најзначајнију личност у Црној Гори. У њима је захтевао да се настави са исплатом плата, да се отворе пазари за Црногорце и да се Никола Болица уклони из Котора. На други и трећи захтев млетачки Сенат је 22. августа 1744. донео позитивну, док питање плата није решено у црногорску корист. Василије је покушавао да оствари и материјалну добит, те је тра- 
жио да му се помогне у обнови Цетињског манастира, за који је тврдио да је разрушен 1692. приликом млетачког повлачења са Цетиња, избегавајући да помене рушење из 1712. али ни овај захтев није усвојен (Томић 1920: Црногорски мийройолий Василије Пейровић, 217-223; Микавица-Васин-Нинковић 2013: 89-90).

Боравак архимандрита у Венецији не би имао већи значај да није постао јабука раздора између њега и митрополита Саве. Око њих су почели да се окупљају главари, што је водило раздору између племена. Суштина сукоба било је питање првенства у Црној Гори, а мучио је земљу од Савиног повратка из Русије (јесен 1744) до краја наредне године. Сава је при томе у Венецији оптуживао свог рођака да је варао дужда фалсификујући потписе и печате. Међутим, Василије у овоме није био сам јер је у Венецији са њим било шест пратилаца. Он је могао бити инспиратор, али је несумњиво имао подршку макар дела главарског слоја, нарочито оног заинтересованог за примање плата. Покушао је да постигне резултате који су суштински одговарали Црогорцима, а владици Сави је управо ово сметало, јер је осетио да би Василије могао да постане утицајнији од њега. Сукоб је стога све више растао, а далматински провидур Ђакомо Болдуо који је посетио Боку (септембар 1745) забележио је да је Црна Гора подељена у две странке, којима су на челу Сава и Василије и да Сава, због страха од ове друге, није смео да му дође у Котор. Тек је у наредном периоду дошло је до смањивања нетрпељивости између ове две стране (Распоповић 1996: 46-48; Томић 1920. Црногорски мийройолит̄ Василије Петировић: 212-217; ИЦГ 1975: 303-306; Микавица-Васин-Нинковић 2013: 88-90).

Одлазак једног архијереја, митрополита Саве, у Руско царство 1742. била је основа за успон архимандрита Василија, а долазак другог, пећког патријарха Атанасија II Гавриловића убрзао је тај успон. Наиме, крајем 1748. и почетком 1749. у Црној Гори и Приморју боравио је патријарх и том приликом упознао архимандрита и за њега се несумњиво заинтересовао. Намера патријарха да из Хабзбуршке монархије поврати драгоцености које је у њу из Пећи однео патријарх Арсеније IV подударала се са амбицијама митрополита Василија. Непознато да ли је са патријархом Црну Гору напустио и Василије, али и ако није то је сигурно учинио ускоро. Као патријархов егзарх дошао је у Сремске Карловце у време када је овде одржаван народни сабор за избор митрополита. Архимандрит је већ крајем јула 1749. стигао на сабор и донео препоруку патријарха Атанасија II да му се изда дозвола како би могао да скупља милостињу на простору Карловачке митрополије. Сам захтев није био необичан, јер су монаси и раније скупљали милостињу на простору Хабзбуршке монархије и то из удаљенијих крајева него што је Црна Гора, нпр. светогорски, синајски, јерусалимски и трапезунтски калуђери. Међутим, како је меркантилистичка политика била на снази у целој држави, она се морала протећи и на цркву. Синод владика и световњака којем је присуствовао и царски комесар барон генерал Христијан фон Хелфрајх као једну 
од првих мера донео је 30. јула 1749. одлуку да се забрањује монасима који нису поданици Хабзбуршке монархије да долазе ради купљења милостиње на њен простор. Одређен је рок од три године колико то још могу да чине синајски, јерусалимски и хиладарски монаси, али уз услов да после три године напусте Монархију. Три године по одласку могу поново послати неког монаха, али он мора имати уредну документацију и гаранцију шест поданика Монархије да ће новац предати манастиру који га шаље. Са овим документима морао се обратити митрополиту како би му он дао дозволу за скупљање милостиње. Владика Василије се обратио бачком епископу Висариону Павловићу, са молбом да му дозволи купљење милостиње. Ипак, владика Висарион није могао да му да дозволу за подручје целе митрополије већ само у границама своје дијецезе, што је и учинио 17. август 1749. год, али је непознато како је на ово реаговао Сабор. У дозволи је стајало да је архимандрит Василије изасланик патријарха и да му учине сваку пажњу и колико могу дају милостиње јер је Пећка патријаршија најзначајнија српска црква. Бачки владика је предвидео и начин на који то има да се чини, односно, да при доласку архимандрита народ са свештенством одреди колику суму могу да дају и да је потом сакупе и предају, а да Василије не иде по свим кућама. Више пута је истакао значај цркве у име које је дошао њен егзарх и указао да та врста помоћи у бачкој епархији није скупљана дуже од двадесет година и да је утолико потребније да је сада предају, јер је Пећка патријаршија у тешком положају, Турци је пљачкају и намећу јој све теже порезе, док ју је претходни патријарх, Грк Јоаникије III Караџа (1739-1746) оставио у дуговима за које кредитори инсистирају да буду наплаћени (АСАНУК, МПА „А“ 357/1749; НМЦГ, АО, 254/1748; Руварац 1912: 57-58; Миловић 1956: 286-290; Нинковић 2012: 267-268).

Други захтев архимандрита Василија односио се на значајније питање, због којег је и упућен у Сремске Карловце. Било је то потраживање патријарха Атанасија II да карловачки митрополит преда његовом егзарху реликвије и црквене драгоцености које је већ поменути патријарх однео из Пећи. Није забележено када је овај захтев предао Сабору, који је на њега одговорио позитивно и предао архимандриту главу светог мученика Евгенија и главу светог Арсенија. Пећки патријарх се обратио писмом 26. августа 1749. митрополиту Павлу Ненадовићу и јавио му да су ове светиње стигле у његову резиденцију и да му то својим потписом и печатом потврђује. Тако је главну мисију која му је поверена архимандрит Василије добро обавио, али ово је био тек део реликвија које су му предате, јер се већина предмета из Пећке патријаршије није налазила у Карловцима, већ у Араду и Карансебешу, седиштима двема, у то време, упражњеним епископијама (АСАНУК, МПА „А“ 1751/60).

Колико дуго је Василије боравио у Хабзбуршкој монархији, односно у бачкој дијецези ради купљења милостиње није познато, а није искључено да се задржао краће време, односно да се после августа није враћао у Монар- 
хију. Међутим, у априлу 1750. поново је био у Срему, када је за Ускрс у манастиру Врднику (Сремска Раваница) боравио пет дана (Ускрс је падао те године 15. априла). Овде је лепо примљен и угошћен од стране братије и игумана Алексија, ${ }^{2}$ како је сам забележио на једном листу Кипријановог рукописа Црквених правила (Даничић 1857: 247). И овог пута настојао је да сакупи по Срему милостињу, за шта је имао пристанак самог митрополита Ненадовића, али и да преузме црквене предмете које није добио 1749. У наредном периоду вероватно није напуштао Хабзбуршку монархију јер је 11/22. јула 1750. био у Сремским Карловцима (Руварац 1898: 26). Овај датум носи документ који је архимандрит Василије својеручно написао и потврдио патријаршијским печатом, а однос се на уговор који је патријарх Арсеније IV за шест стотина гроша у Скопљу склопио са неким Јеврејином Исуфиковићем (Јусуфиковић), а као јемци овог документа била су тројица митрополита Атанасије коласијски, Симеон самоковски и Алексије Андрејевић ужички. Василије је навео да је патријарх Атанасије II овај дуг платио поменутом Јеврејину, јер су јемци или умрли или избегли, те да митрополит Ненадовић, по патријарховој поруци, не исплаћује овај износ никоме, јер је било управо таквих покушаја. ${ }^{3}$ У ово време владали су добри односи између митрополита Ненадовића и архимандрита Василија, али нису такви остали још дуго (Руварац 1898: 39).

После овог боравио је архимандрит Василије Петровић краће време у Београду, што је био један од његових најважнијих одлазака овде, јер га је патријарх Атанасије II 2. септембра 1750. хиротонисао за митрополита и истовремено га поставио за егзарха пећког трона. ${ }^{4}$ После хиротоније поново је прешао у Хабзбуршку монархију. Овде је ишао по фрушкогорским манастирима и покушавао да скупи милостињу за Пећку патријаршију, ${ }^{5}$

\footnotetext{
Игуман (проигуман) Алексије Гавриловић пореклом Острогонац био је један од образованијих фрушкогорсих монаха. Визитациона комисија митрополита Павла Ненадовића 1753. за њега је записала да зна да чита и поје, као и мађарски и немачки, што није био чест случај. Због тога га је митрополит из манастира послао у Арад да помаже у служби и епархијским пословима епископу Синесију Живановићу (Руварац 1903: 45)

3 Митрополит Атанасије се не помиње после 1737. док су Турци после мучења обесили 1737. митрополита Симеона Поповића пошто се сумњало да је инспиратор рата са Хабзбуршком монархијом, односно, извесно је да је био заговорник рата. Податак да је неко избегао односио се на митрополита Алексија, кога је патријарх Aрсеније IV поставио као ипопсифија за ужичко-ариљског дијецезана крајем 1736, да би га следеће године хиротонисао. Са патријархом и још двојицом епископа напустио је епархију услед повлачења хабзбуршке војске са простора јужно од Саве и Дунава и 1741. постао костајничко-лички (костајничко-зринопољски) владика. Јурисдикција му је проширена и на предео тзв. Северинско-марчанског владичанства, у коме је Беч 1743. забранио постављање новог владике. Умро је 1749. године (Сава 1996: 10-11, 41, 452; Нинковић 2012: 264)

4 У самом чину хиротоније поред патријарха учествовали су београдски митрополит Вићентије Стефановић (године 1758. је био пећки патријарх, али је исте умро у Цариграду) и рашки митрополит Гаврило Георгијевић (Руварац 1898: 26; Сава 1996: 73, 101)

5 Почетком новембра 1750. још увек је био у Сремским Карловцима одакле се јавио игуману Велике Ремете Атанасију Исаијевићу. Из писма се може видети да је непосредно пре тога Василије скупљао милостињу у фрушкогорским манастирима са Ненадовићевом дозволом, за Пећку патријаршију и да је није скупио само у Бешенову, где није ни отишао и у Јазку, где га нису пустили да уђе. Такође, иако је пут по манастирима започео у Великој Ремети овде није скупио милостињу,
} 
али је и овога пута његов главни задатак био да преузме преостале предмете манастира Пећке патријаршије. ${ }^{6}$ Коначно се тада приступило озбиљније читавом послу. Најпре је било неопходно да се утврди шта се од предмета налази на подручју Карловачке митрополије. То је учињено тако што су упоредили списак пренетих ствари који је састављен 1740. са списком ствари који су се до тада сачувале. Отежавајућа околност је била та што се већина ствари и даље налазила изван Карловаца, у Араду и нарочито у Карансебешу код владике Јована Георгијевића, иначе особе која је била веома блиска покојном патријарху. Пошто је списак прегледан договорили су се митрополити Павле и Василије да ни садашњи, ни будући, пећки патријарси не могу тражити нешто ван поменутог списка да буде враћено у Пећ (пошто је утврђено шта је до тада употребом пропало), нити садашњи, ни будући карловачки архиепископи не могу тражити да им буде исплаћен трошак од 3000 форинти који је начињен да би се сви ови предмети сачували и сместили на сигурно место. На овај начин нађен је извесни modus vivendi за предају предмета и постигнут договор како би биле избегнуте несугласице. Поред тога, митрополит Павле Ненадовић је обећао да ће у најскоријем року сви предмети који нису у Карловцима бити овде пренети и предати патријарховом егзарху. Ово је потврдио својим потписом и патријаршиским печатом и митрополит Василије 3. октобра 1750. Чинило се да ће сви проблеми бити решени на миран начин, јер је егзарх одмах добио све што се налазило у Карловцима, али се још неко време задржао у Срему ради скупљања милостиње за Пећку патријаршију (Рајковић 1884: 7; Руварац 1898: 26).

Митрополит Василије Петровић упутио се крајем 1750. без знања патријарха и карловачког митрополита у Беч са два циља, да заинтересује Двор за судбину Црне Горе и да се царици потужи на митрополита Ненадовића, незадовољан што до тада није добио све предмете Пећке патријаршије. ${ }^{7}$ Већ крајем године митрополит Василије је примљен у аудијенцију код Марије Терезије и том приликом јој је предао један меморијал и једну молбу. У њима је, у име пећког патријарха и српских православних епископа који живе у Османском царству, молио да буду враћене реликвије и црквене драгоцености које је из Пећке патријаршије однео патријарх Aрсеније IV.

већ је само угошћен и лепо примљен. Сам Василије каже да га је било срамота да онда од братије тражи милостињу (игуман се није налазио у манастиру) те зато сада моли да је скупе и пошаљу у Карловце (Рајковић 1884: 7).

6 Пре саме хиротоније постојала је и идеја да архимандрита Василија Сабор епископа пећке патријаршије пошаље ради материјалне помоћи у Русију. У том циљу је написано писмо које су уз патријарха Атанасија II потписали београдски митрополит Вићентије Стефановић, херцеговачки Филотеј и рашки Гаврило. Међутим, до пута није дошло. (НМЦГ, АО 3/1750; Вуксан 1938: 36-37. Руварац 1898: 40-41).

7 Физички удаљени Арад и Карансебеш су само отежавали преношење ствари, а у Араду је морало бити и административних препрека, наиме, епископија са центром у овом граду је била седисвакантна и њоме је администрирао један од најумнијих Срба тог времена раковачки архимандрит Синесије Живановић. Све док не би био потврђен и уведен у епископско достојанство он би тешко могао ове ствари послати из своје епархије. 
Поред тога, тражио је да му се дозволи да од православних епископа и верника скупља прилоге. Нарочиту пажњу је поклонио покушају да Марију Терезију заинтересује за Црну Гору. У том циљу није презао од фалсификовања података. Истицао је како су Црногорци учинили велике услуге аустријском Двору у прошлости, јер је патријарх Арсеније III Црнојевић био пореклом из Црне Горе у којој је скупио велики број бораца који су помагали царској војсци. Ово је, по Василију, довело до више војних турских интервенција, што је био сасвим извесно измишљени податак. Наиме, становништво Црне Горе није у време Великог бечког рата своју судбину везивало за Хабзбуршку монархију већ за Млетачку републику, због чега јесте уследила турска офанзива, али се само једна (из 1692) коју је водио скадарски санџак-бег Сулејман-паша Бушатлија завршила поразом Црногораца (Микавица-Васин-Нинковић 2013: 56-58). ${ }^{8}$ Ово међутим, није био једини нетачан податак који је изнео, продужавајући у набрајању црногорске помоћи Монархији навео је како су Срби и Клименти који су се населили са патријархом Арсенијем IV такође из Црне Горе, при чему је поново истакао како су у време рата 1737-1739. између Хабзбуршке монархије и Османског царства Црногорци помогали Монархију због чега су их пуних седам година нападали Турци који су ипак, на крају, поражени. Ова тврдња је била само делимично тачна и односила се пре свега на брдска и делимично херцеговачка племена која јесу ратовала кратко време на аустријској страни и због тога била изложена турској одмазди, за разлику од црногорских племена (Микавица-Васин-Нинковић 2013: 85-87). Поред приказивања великог значаја Црне Горе за Хабзбуршку монархију владика Василије је обећавао, као једини истински вођа Црне Горе, царици Марији Терезији да ће увек оружјем помагати тежње њене државе. На документа која је предао царици ставио је патријаршијски печат, иако је било извесно да патријарх није учествовао у њиховом састављању, нити да је у том смислу дао инструкције свом егзарху. Царица је саслушала митрополита Василија, а његове захтеве је проследила на решавање Илирској дворској депутацији, као институцији надлежној за Србе у Хабзбуршкој монархији, којој се у то време на челу налазио гроф Фердинанд Коловрат (Руварац 1898: 29-30; Швикер 1998: 117-118). ${ }^{9}$

У Илирској дворској депутацији брзо су сазнали да је митрополит Петровић већ био у Карловцима где му је предат део предмета, а да је део остао

8 Исту лажну тврдњу изнео је Василије и у Исйорији о Черној Гори коју је штампао у Русији 1754. Овде је опет навео како су Црногорци пратили патријарха 1689. кроз Босну док се нису сјединили са царским трупама (Петровић 1951: 37-39).

9 Фердинанд Алојз Коловрат Краковски потиче из старе чешке племићке породице. Био је на челу комисије за реорганизацију управе у Банату, за који је саставио план развоја на основу меркантилистичке политике Двора. По оснивању Дворске комисије за Банат, Трансилванију и Илирик 1745. дошао је на њено чело, де се задржао и када је две године касније она претворена у Илирску дворску депутацију (Дворска депутација за Трансилванију, Банат и Илирик). У одбрани ингеренција ове институције од напада Угарске дворске канцеларије изнео је тврдњу да су Срби од добијања Привилегија patrimonium Domus Austriacae, односно да је једино владар надлежан за Србе (СБР 2011 (Точанац): 184). 
у Араду и Карансебешу, при чему му је имао обећање Павла Ненадовића да ће их у најкраћем року добити. На основу захтева који је изнео митрополит Василије, у име Марије Терезије обратио се писмом митрополиту Ненадовићу, 3. фебруара 1751, гроф Коловрат и навео му садржај Василијеве молбе и захтев да Двору достави списак ствари које се налазе у Карловцима, Араду и Карансебешу. Такође, писмо је садржавало и наредбу да све ствари буду допремљене до Карловаца и да их, ако за то нема неке препреке Ненадовић преда Василију, а у случају да има проблема да јави владарки о чему је реч. Марија Терезија је још поручила митрополиту Ненадовићу да у вези са Василијевом молбом ради добијања дозволе за сакупљање милостиње међу православцима у Хабзбуршкој монархији, пренесе Василију да то никако не може чинити у Банату и Ердељу, јер је тамо становништво веома сиромашно, док ако жели да то чини у Угарској мора се обратити Угарској дворској канцеларији. Ово је, међутим, значило суштинско одбијање јер је од раније постојала царска резолуција да се у Хабзбуршкој монархији не могу остављати завештања нити купити милостиња за османске поданике јер се прилив средстава, на овај начин, из Османског царства у Монархију, није могао очекивати. Истовремено, усменим путем је саопштено владици Василију да нема шта више да очекује у Бечу, већ да се упути у Сремске Карловце где ће му митрополит Ненадовић предати све предмете манастира Пећке патријаршије (АСАНУК, МПА „А“ 357/1749, 60/1751; Руварац 1898: 39-43; Руварац 1912: 56-58; Вуксан 1938: 96-97; Распоповић 1996: 51; Микавица-Васин-Нинковић 2013: 91).

Владика Василије се тада заиста и упутио у Карловце, али заобилазним путем, који је ишао преко Арада. При томе је своју путну исправу користио као патент за сакупљање милостиње, што је био први проблем. Међутим, како је становништво овде заиста било сиромашно и није увек могло да да̂ милостињу, Василије је почео да прети бацањем анатеме ако је не би добио. О свему што се дешавало на путу вест је пре Василија стигла у Сремске Карловце, у које је он дошао у другој половини марта 1751. Остаје отворено питање да ли се надао да његови поступци неће изазвати реакцију и да лично због тога неће имати никаквих проблема. Такође, непознато је колико је добро, до тада, упознао митрополита Павла Ненадовића, али се после свега намеће мишљење или да није добро проценио карловачког митрополита или да у потпуности није познавао уређење Карловачке митрополије, њену јурисдикцију, али ни уређење саме Хабзбуршке монархије. Једино се на овај начин могу оправдати његови лакомислени иступи против Павла Ненадовића у Бечу или непримерено понашање приликом повратка из њега. Чим је владика Василије стигао у Карловце одузет му је патријаршиски печат и затворен је у манастир Крушедол. Ненадовић ово није урадио на своју руку, већ је на Синоду донета одлука коју су потписали митрополит и пакрачки владика Софроније Јовановић, карлштадски Данило Јакшић и двојица архимандрита, администратори упражњеним епархијама Синесије Жива- 
новић и Арсеније Теофановић (Руварац 1989: 43; Швикер 1998: 117-119; Микавица-Васин-Нинковић 2013: 90-91).

О догађајима са пута митрополита Петровића, одузимању патријаршиског печата и затварању у Крушедол обавештени су патријарх Атанасије II и Двор. Истовремено су сви предмети из Пећке патријаршије скупљени у Карловцима, о чему је обавештен патријарх, али се чекало његово писмо као одговор на митрополитово питање шта да ради са њима и да ли да их преда митрополиту Василију, који је на Синоду оптужен да је без знања и дозволе патријарха и митрополита Ненадовића отишао у Беч, где се тужио за ствари које му нису предате иако су обећане у најскоријем року. Затим, замерено му је што је тражио дозволу за купљење милостиње и поред царске резолуције да се ово не сме дозволити лицима која долазе из Османског царства. Утолико је ово било опасније по Павла Нендовића који му је дозволио да млостињу купи по Архидијецези. Оно што му је нарочито уписано као велик преступ била је чињеница да се мешао у јурисдикцију епископа Карловачке митрополије и то без знања и неопходне дозволе дијецезана, а нарочито претња анатемом у случају не давања милостиње. Синод је одлучио да по притварању митрополита сачека одлуку патријарха и Двора. Одговор на поступак преме Василију из Беча је стигао 8. јуна 1751. и у њему је стајало да се подржава став митрополита Павла Ненадовића и поступак Синода (Руварац 1898: 44). Чини се да ни патријархов одговор није стигао брзо, јер је Василије, којег је поново предвидео за особу која би пренела све драгоцености Пећког манастира, три месеца боравио у Крушедолу. Пошто је Павле Ненадовић добио одговоре од патријарха и Двора предао је Василију спорне предмете и упутио га ван Хабзбуршке монархије. Међутим, он није отишао патријарху у Пећ, већ на Цетиње где је понео и драгоцености, које је на путу преко Млетачке републике нудио да покаже дужду (АСАНУК, МПА „А“ 60/1751; Руварац 1898: 46-47; Станојевић 1979, 96-100; Распоповић 1996: 51).

Овим се завршио најзначајнији и најдужи боравак митрополита Василиja у Хабзбуршкој монархији. Током њега он се више пута компрпмитовао у очима Двора и карловачког митрополита те се није могао надати значајнијим резултатима било по питању интересовања Двора за Црну Гору, било по питању личне промоције. Приметно је да се Василије није најбоље снашао у Монархији, али ни међу карловачком јерархијом. Он је потицао из сасвим другог окружења, где није било сложене бечке администрације, нити релативно уређене јерархије каква је била карловачка. На простору Црне Горе Василије је био ако не још увек најутицајнија, оно међу најутицајнијим личностима, коју је следила већина становника. На простору Карловачке митрополије то су били њени епископи, а пре свих архиепископ Павле Ненадовић, који, по оцени Јована Скерлића, није био ни мало благ према било коме ко би му се замерио (Скерлић 1966: 69-70). Током управе Карловачком митрополијом (1749-1768) овај јерарх је показао чврсту вољу и одлучност да 
реформише духовни живот и учини све да заштити православне поданике Марије Терезије од католичког прозелитизма. Његове везе у Бечу нису биле слабе и контакте са виђенијим људима имао је још од прве четвртине XVIII века. Међутим, оптужбе на његов рачун од стране владике Василија Петровића у Бечу, могле су имати последице не само по њега лично, већ и по српски народ. Још пре него што је постао митрополит Ненадовић је могао увидети како се положај Срба у Хабзбуршкој монархији погоршава. Период од четрдесетих година XVIII века до 1751. био је нарочито тежак, прозелитизам католичке цркве јачао је у Хрватској, Славонији, Жумберку, Великом Вараду и околини Будима, комешања су се осетила у хрватском делу Војне границе, што је 1751. резултирало Кијуговом буном. Развојачење Потиско-поморишке војне границе је увелико било у току и миграције становништва су биле све интензивније, док су дискриминаторски закони у Хрватској уперени против Срба добијали све више на снази. Митрополит се спремао да поведе борбу за заштиту Срба и у том циљу тражио је потпуно покоравање православних верника, јер се свака непослушност могла тумачити као отказивање верности Хабзбуршком дому, што би био повод за сужавање Привилегија. У тако тешким околностима није ни смео, ни могао, да допусти непромишљену делатност егзарха пећког трона. ${ }^{10}$

Боравак митрополита Василија Петровића у Хабзбуршкој монархији 1750/51. прошао је неславно, а његово компромитовање у Бечу показало му је да мора бити знатно опрезнији и да у Хабзбуршкој монархији неће моћи да нађе савезника. Како је све везе са Млетачком републиком држао у рукама митрополит Сава Петровић решио је да отпутује у Русију, не би ли тамо постигао већи лични успех и корист за Црну Гору. Са овом намером упознао је митрополита Саву и главарски Збор и са њиховом препоруком у пролеће 1752. године кренуо на пут. У Русији је боравио до 1754. и приликом повратка дошао је током августу у Беч. Царици Марији Терезији овог пута је предао тужбу против архиепископа Павла Ненадовића због дешавања

10 У том смислу важно је указати на честе тенденциозности са којима је писано о Василијевом боравку у Хабзбуршкој монархији, нарочито одузимању патријаршијског печата и затварању у Крушедол, до чега је дошло јер није узиман у обзир положај Срба у Хабзбуршкој монархији нити настојања Павла ненадовића да исти поправи. Закључци по којима је Василије намерно ометан, затваран и прогањан, без обзира што је кршио законе и цркве и државе на чијој се територији налазио, последица су оваквог, једностраног посматрања догађаја. Примера ради навођено је како је митрополит Ненадовић био љубоморан на Василијев слободан одлазак у Беч и аудијенцију код царице. Међутим, пренебрегава се чињеница да је још од времена патријарха Арсенија IV постојала наредба по којој Срби нису смели да долазе на Двор без претходе писмене најаве разлога посете и писменог одобрења исте. Два пута када је то учињено, ради сазивања изборних сабора 1748. и 1749. најстроже су укорени и запрећено им је санкцијама. У оваквим околностима ни Ненадовић није могао да одобри поступак одласка без најаве Василија, јер је могао да страхује од последица по Србе. Излишне су и оцене да је Василије отишао у Црну Гору где га нико није могао ухапсити ни малтеретирати (мада нема никаквих доказа да га је ико у Монархији малтеретирао) или да је напустио негостољубиви Срем (у коме је више пута приман и по коме је сакупљао милостињу и био лепо дочекан по фрушкогорским манастирима, што је лично бар два пута признао). (Даничић 1857: 247; Рајковић 1884: 7; Станојевић 1978: 98-99) 
из прве половине 1751. године. Василије је тражио сатисфаксију за наводне увреде и малтретирања која је тада доживео, и то такву коју би могао да види народ у Црној Гори, јер би тек у том случају остао одан интересима Беча. Овакав поступак је био дирекна последица Василијевог политичког успона који има да захвали боравку у Русији. Међутим, то на бечком двору није играло већу улогу, па је царица својерочно на Василијевом захтеву записала „да се о овоме саслуша митрополит [Павле Ненадовић] сматрам да је захтев безочан, али због Русије и саме ствари ово треба испитати“"(Швикер 1998: 119-120). Захтев је са овим коментаром упућен Илирској дворској депутацији на челу са грофом Карлом Фердинандом од Кенигсег-Ерпса. Поштујући жељу владарке Депутација је затражила објашњење од Павла Ненадовића, на које није морала дуго да чека. Већ у септембру митрополит је послао одговор у коме је побројао све Василијеве преступе учињене не само 1750/51, већ и те 1754. када је пролазећи кроз Будим и Пешту у српској цркви ушао у владичански трон делећи благослове што никако није смео да ради на подручју Карловачке митрополије без његове дозволе. ${ }^{11}$ Истовремено Василије се предтављао као патријархов изасланик што више није био. Поред овога Ненадовић је истакао главни аргумент, бар је он такав био у очима Беча, против митрополита Василија, указујући какве је све везе имао са руским посланством у Бечу и да је боравио дуже време у Русији, што је на Двор сигурно оставило најјачи утицај, јер се плашио да ће на територији Монархије агитовати у корист Русије. Ово сазнање је још једном уверило Беч да је митрополит Павле Ненадовић исправно поступио када је Василија 1751. притворио у Крушедол и да, стога, у његову оданост не би требало сумњати, а тужби Василија Петровића придавати никакав значај. Напротив, Василија би требало протерати из Монархије и забранити му даљи улазак у њу, а још мање пролазак кроз њу за Русију, како би биле уклоњене све непријатности, укључујући и оне које би због њега Беч могао да има са Цариградом. ${ }^{12}$ Поред овога тужба је још једном разматрана крајем новембра 1754. када је гроф Кауниц указао да је текст Василијеве тужбе потекао из пера руског амбасадора грофа Кајзерлинга, што је у очима Беча могао да буде аргимент више да му се забрани сваки улазак у Хабзбуршку монархи-

11 Чини се како је митрополит Павле Ненадовић, овог пута, брже и лакше него 1751. отклонио сумњу са себе да је крив за оно за шта га је Василије Петровић оптуживао. Било је потребно само једно писмо да се одбрани и да укаже Бечу на Василијеве везе са Русијом. Са друге стране митрополит Ненадовић је и овог пута водио више рачуна о другим проблемима, пре свега верским притисцима и спречавању српских миграција у Русију. Процес унијаћења и сукоби између жупанијских власти и манастира (због чега је исте године дошло до тзв. Фекетине реамбулција) били су веома интензивни упрво у време ове Василијеве тужбе (АСАНУК, МПА „А“ Protocollum Exhibitorum Registratura Archiepiscopalis Carlovitzensis et Inclyta Nationis Illyrico Rasciana de Anno 1754 usque ad Annum 1756).

12 Последња одредба о забрани проласка кроз Монархију на путу за Русију у неколико је поштована када је Василије на свом трећем путу за Петроград 1765. стигао у Беч и када је примљен у аудијенцију код Марије Терезије. Она му је тада дала путне исправе, али не да иде преко територије Монархије, већ да се одмах упути према Пруској и да преко ње настави путовање, што је Василије октобра 1765. и учинио. Душан Вуксан 1939: 369-371; Станојевић 1978: 180-183; Распоповић 1996: 78-80). 
jу, а сумња за било какву кривицу буде отклоњена са поступака карловачког првојерарха (Драговић 1895: 9-11; ИЦГ 1975; 327-328; Швикер 1996: 120121; Црна Гора и Русија 2011: 598-604, 608-610, 612-613; Микавица-ВасинНинковић 2013: 95).

Крајем XVII и током XVIII века јавио се у српском друштву на простору Херцеговине, Црне Горе и Брда покрет за еманципацију од власти Османског царства. Иако је његову генезу могуће пратити од раније са Великим бечким ратом и делатношћу цетињског митрополита Висариона Бориловића конкретизује се у виду устанка и савеза племена са Млетачком републиком. Овакву политику наставио је први Петровић-Његош на челу Цетињске митрополије, владика Данило, али је покушао да се у намери ослобођења ослања и само на сопствене снаге. Иако је овај покушај био безуспешан оставио је дубоког трага у сећању народа и омогућио даљи рад на ослобођењу при чему би оно било усклађено са политикама европских сила, пре свих Млетачке републике, Хабзбуршке монархије и Руског царства. Како је наследник владике Данила Петровића на челу митрополије, владика Сава, брзо показао неактивност у спољној политици, иницијативу је преузео његов млађи рођак, најпре архимандрит, а од 1750. митрополит Василије Петровић.

Успон архимандрита Василија на политичкој сцени почео је 1742. када је митрополит Сава отпутовао у Русију, а њега оставио као свог заменика да управља Цетињском митрополијом. Ситуација у којој га је оставио није била повољна јер су млетачко-црногорски односи западали у све већу кризу, а Василије је настојао да их реши у духу оданости Млетачкој републици. У том циљу боравио је неколика месеци у Венецији где је преговарао око побољшања односа, али и покушао да оствари личну материјалну корист. Иако у овом другом није имао успеха јасно се показало да је спреман на разне акције, да му не мањка политичког дара, али да још увек није стекао довољно искуства у дипломатским односима. Ово се осетило и у његовој другој, знатно озбиљнијој дипломатској мисији коју је имао у Хабзбуршкој монархији, где је боравио у више наврата у периоду 1749-1751. и поново 1754. Василијев задатак у Хабзбуршкој монархији био је да врати предмете које је са собом, приликом напуштања Пећи, понео патријарх Арсеније IV Јовановић. Као егзарх патријарха Атанасија II Гавриловића требало је да их преузме од карловачког митрополита Павла Ненадовића. Боравак у Хабзбуршкој монархији искористио је и за скупљање милостиње за Пећки манастир. Настојао је и да заинетересује Двор за судбину Црне Горе те је у том циљу примљен у аудијенцију код царице Марије Терезије. Овом приликом тужио се владарки да није од митрополита Павла Ненадовића добио све предмете Пећког манастира, не рекавши да су му они у Карловцима обећани. Овај поступак био је један од узрока за озбиљне последице које је имао у Карловцима марта 1751. 
Поновни Василијев долазак у Сремске Карловце после боравка у Бечу, злоупотребе јурисдикције карловачке јерархији и претње бацањем анатеме на становништво које није спремно да да̂ милостињу, изазвало је оштру реакцију Архијерејског синода и митрополита Павла Ненадовића. Одузимање патријаршијског печата, слање извештаја у Пећ и Беч и затварање Василија у Крушедол била је мера коју су сложно предузели митрополит и епископи Карловачке митрополије. Оштрина и одлучност са којом су реаговали може се схватити тек ако се у обзир узму сложеност ситуације у којој су се српска црква и народ у Хабзбуршкој монархији налазили последњих године. За непуне две године сменила су се три архијереја на челу Митрополије, одржана су два црквено-народна сабора, развојачење Потиско-поморишке границе је било у пуном јеку, руска агитација и миграције су узимале све више маха, милитаризација пукова Старих војних граница је изазивала све веће незадовољство Срба у њима, верски притисци нарочито на рубним подручјима српског етничког простора су били интензивирани, а покушаји да се оснаже дискриминаторски закони у Хрватској све чешћи. Са оваквим проблемима у настојању да заштити своје вернике и њихов положај Павле Ненадовић је инсистирао на безрезервној оданости Хабзбурговцима у страху да буне и отпор не буду протумачени као отказивање послушности што би водило даљој деградацији или губитку Привилегија. Зато се морала спречити свака сумња која би пала на народ па и на митрополита, а овог другог сумњи Беча управо је препоручио Василије Петровић. Иако је Василије после три месеца напустио Крушедол и добио преостале предмете, сукоб са митополитом Ненадовићем није заборавио, па се против њега поново тужио Марији Терезији 1754. али је овог пута, пошто је Ненадовић образложио своје поступање из 1751, протеран из Хабзбуршке монархије, где му је забрањен даљи улазак. Василијев боравак и акције у Монархији показали су да се он ту тешко сналазио и да његови покушаји да оствари личну корист, не само да нису добро прошли у Млетачкој републици него и овде, али су били својеврсна школа да му се такав неуспех не понови у Руском царству, где је успео у много чему што није могао у претходно поменутим државама. Зато су мисије у Млетачкој републици и Хабзбуршкој монархији Василија Петровића, иако се не могу сматрати потпуно неуспешним, пре свега послужиле амбициозном митрополиту као животна и политичка пракса која му је била од помоћи у будућим дипломатским мисијама, политичким акцијама и личним плановима.

\section{ИЗВОРИ}

необјављени:

Архив Српске академије наука и уметности у Сремским Карловцима, Митрополијскопатријаршијски архив, фонд „А“ (у тексту АСАНУК, МПА „А“)

Народни музеј Црне Горе, Архивско одељење (у тексту: НМЦГ, АО) 
објављени:

Вуксан, Душан (1938). Историјска грађа. Епоха митрополита Саве и Василија, Зайиси, XIX, Цетиње 33-39.

Вуксан, Душан (1939). Историјска грађа. Три документа из разних времена, Зайиси, XXI, Цетиње 362-378;

Даничић, Ђура (1857). Рукописъ Кипр1яновъ., Гласник Друшйва србске словесносӣи, IX, Београд 245-255.

Драговић, Марко (1895). Майеријал за ист̄орију Црне Горе, Споменик Српске краљевске академије, Београд, 44 стр.

Петровић, Василије (1951) Ист̄ория о Черной Горы, фототипско издање, Београд, Научно друштво народне републике Црне Горе и Матица српска.

Петровић, Растислав В. (1981). Племе Кучи 1684-1796, Београд, Народна књига.

Рајковић, Ђорђе (1884), Стара писма, Глас исииине, Нови Сад 7.

Руварац, Димитрије (1898) Василије Петровић, Сйоменик Срйске краљевске академије, XXXIII, Београд 23-56.

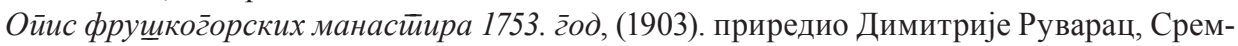
ски Карловци.

Руварац, Димитрије (1912) Препорука владике бачког Висаријона Павловића дана архимандриту пећком Василију Петровићу, Архив за истиорију срйске йравославне карловачке мийройолије, Сремски Карловци 56-58.

Црна Гора и Русија (2011). Подгорица-Москава, Историјски институт Црне Горе, Институт за руску историју РАН, Амбасада Црне Горе у Русији, САНУС.

\section{ЛИТЕРАТУРА}

Дашић, Миомир (2011). Васојевићи од ӣомена до 1860, Никшић, Издавачки центар Матице српске.

Мијушковић, Славко (1954). Племе Никшићи у Морејском рату, Истиоријски зайиси, књига Х, Цетиње, Историјски институт СР Црне Горе.

Мијушковић, Славко (1955). Догађаји у Црној Гори од појаве Милорадовића до Нуман-пашиног похода: (1711-1714), Истиоријски зайиси, Цетиње, 173-214.

Микавица Дејан-Васин Горан-Нинковић Ненад (2013). Ист̄орија Срба у Црној Гори 1496-1918, Нови Сад, Прометеј.

Миловић, Ђорђе Д. (1956). Дјелатност млетачких власти у вези доласка пећког патријарха Атанасија у Приморје почетком 1749., Исӣориски зайиси, ХІІ, Цетиње 280-295.

Нинковић, Ненад (2012). Црквено-народни сабор и Архијерејски синод из 1749. године, Истираживања, 23, Нови Сад 259-281.

Петровић, Растислав В. (1997). Владика Данило и владика Сава (1697-1781), Београд, ИШ „Стручна књига“ д.д.

Распоповић, Радослав М. (1996). Дийломайија Црне Горе: 1711-1918, Подгорица, Историјски институт Црне Горе.

Сава, епископ шумадијски (1996), Српски јерарси, Београд-Подгорица-Крагујевац, ЕВРО-УНИРЕКС-Каленић.

Скерлић, Јован (1966). Српска књижевност у XVIII веку, Београд, Просвета.

Српски биографски речник (2011), књига 5, Нови Сад, Матица српска. 
Станојевић, Глигор (1955). Црна Гора у доба владике Данила, Цетиње, Историјски институт НР Црне Горе.

Станојевић, Глигор (1962). Црнгорска и брдска племена у вријеме Аустријско-руског рата против Турске (1735-1739), Исӣоријски зайиси, Титоград 380-402.

Станојевић, Глигор (1979). Мит̄ройолиӣ Василије Пеӣровић и њег̄ово доба (1740-1766), Београд, Историјски институт-Народна књига.

Станојевић, Глигор (1958). Пут архимандрита Василија Петровића у Венецију 1744 године, Истиоријски зайиси, XIV, Цетиње 260-285.

Ист̄орија Црне Горе (ИЦГ)(1975). трећа књига (написао Глигор Станојевић), Титоград. Историјски институт Црне Горе.

Томић, Јован Н. (б.г). Пайријарх Арсеније ІІІ Црнојевић йрема Млечићима и Ћесару: 1685-1695., б. м. б. и.

Томић, Јован Н. (1907). Црна Гора за Морејског̄ райа: (1694-1699), Београд, Државна штампарија Краљевине Србије.

Томић, Јован Н. (1920). Турски поход на Црну Гору 1712. год., Глас Српске краљевске академије, 56, Београд 153-196.

Томић, Јован Н. (1920). Црногорски митрополит Василије Петровић и покушај емиграције Црногораца у Русију 1754-1757 год, Глас Срйске краљевске академије, 56, Београд 209-267.

Томић, Јован Н. (1932). Поход Нуман-паше Ћуприлића на Црну Гору 1714. године, Глас Срйске краљевске академије, 75, Београд 47-132.

Швикер, Јохан Хајнрих (1998). Политиичка ист̄орија Срба у Уг̄арској, Нови Сад-Београд, Матица српска-Гутенбергова галаксија.

Владан С. Гавриловић, Ненад Ђ. Нинковић

\author{
ДИПЛОМАТСКЕ МИСИЈЕ АРХИМАНДРИТА \\ И МИТРОПОЛИТА ВАСИЛИЈА ПЕТРОВИЋА У МЛЕТАЧКОЈ \\ РЕПУБЛИЦИ И ХАБЗБУРШКОЈ МОНАРХИЈИ
}

\begin{abstract}
SUMMARY
Vasilije Petrovic, metropolitan of Cetinje, played significant role in the past of Montenegro, Brda and Herzegovina from 1742, when he was temporarily running the Metropolitante on behalf of his uncle metropolitan Sava, until 1766 when he died in Russia. Skillfull and ambitious he knew exactly what the real forces of Montenegro are as well as that in the event of taking any action, especially towards liberation, Montenegro needed support and help of allies. That is why he was trying to relate his politics to the Most Serene Republic of Venice, Habsburg Monarchy and Russian Empire. With the last one he had the most success, but he gained diplomatic experience from the first two. The time he had spent in Habsburg Monarchy was in that sense crucial, especially his first visit which had lasted with brief interruptions from 1749-1751.
\end{abstract}

